\title{
MENINGKATKAN PRESTASI BELAJAR SISWA KELAS VIII.F SMP NEGERI 33 SURABAYA PADA MATA PELAJARAN IPS MATERI PRANATA SOSIAL DENGAN MODEL PEMBELAJARAN SNOWBALL THROWING
}

\author{
Mudjianingsih \\ SMPN 33 Surabaya \\ mudjianingsih.33@gmail.com
}

\begin{abstract}
Abstrak
Kegiatan bertanya pada mata pelajaran IPS merupakan bagian penting dalam pembelajaran, dimana kegiatan bertanya berfungsi untuk menggali informasi dari siswa, mengkonfirmasi apa yang sudah diketahui, dan mengarahkan perhatian pada aspek yang belum diketahuinya. Berdasarkan hasil pengamatan kondisi dalam kelas VIII F SMPN 33 Surabaya yang kurang antusias dalam mengajukan pertanyaan, sehingga digunakan model pembelajaran yang sesuai, salah satu model pembelajarannya adalah model pembelajaran Snowball Throwing. Dalam penelitian ini terdapat 4 tujuan penelitian yaitu, untuk megetahui: 1) Penerapan model pembelajaran Snowball Throwing, 2) Aktivitas siswa 3) Hasil belajar siswa, 4) Kendala yang dihadapi dan solusinya. Penelitian ini termasuk dalam Penelitian Tindakan Kelas dengan pendekatan kualitatif yang dilakukan di kelas VIII F SMPN 33 Surabaya yang berjumlah 32 siswa. Dalam penerapan Snowball Throwing terdiri dari dua siklus yang meliputi tahap perencanaan, tahap tindakan, tahap observasi dan tahap refleksi. Teknik pengumpulan data minat bertanya dalam penelitian ini menggunakan lembar observasi minat bertanya, dan untuk hasil belajar siswa menggunakan tes pada siklus I dan II. Analisis data menggunakan reduksi data, observasi data, dan penarikan kesimpulan. Hasil penelitian ini menunjukkan bahwa: 1) Penerapan model pembelajaran Snowball Throwing meningkatkan keaktifan siswa, 2) Ketuntasan hasil belajar siswa pada tes siklus I adalah $68,42 \%$, untuk tes Siklus II ketuntasan meningkat menjadi 100\%, kriteria ketuntasan pada siklus II ini masuk dalam kategori Sangat Baik, 3) Kendala yang dialami peneliti adalah kurangnya keseriusan siswa dalam KBM, dan solusinya siswa harus mentaati aturan model pembelajaran tersebut.
\end{abstract}

Kata Kunci : Meningkatkan Hasil Belajar, Snowball Throwing.

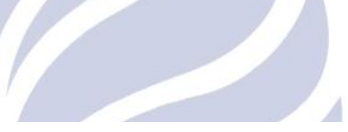

\begin{abstract}
Asks activities in social studies is an important part of learning, in which the activities asked serves to gather information from students, to confirm what was already known, and to bring attention to the aspect of the unknown. Based on observations of conditions in F class VIII SMPN 33 Surabaya were less enthusiastic in asking questions, so use appropriate learning models, one model of learning is learning models Snowball Throwing. In this research there are four research objectives, namely, to megetahui: 1) The application of learning models Snowball Throwing, 2) Activity 3 students) student learning, 4) Obstacles encountered and solutions. This study was a classroom action research with qualitative approach in class VIII F SMPN 33 Surabaya totaling 32 students. In the application of Snowball Throwing consists of two cycles covering the planning stage, the stage of action, observation and reflection stages. Data collection techniques interest asked in this study using observation sheet interest to ask, and for student learning outcomes using the test cycle I and II. Data analysis using data reduction, observation data, and drawing conclusions. The results of this study show that: 1) The application of learning models Snowball Throwing increase student activity, 2) Complete test results of students in the first cycle was $68.42 \%$, for the second cycle tests increased to $100 \%$ thoroughness, completeness criteria in this second cycle entry in the category of Very Good, 3) the problem faced by researchers is the lack of seriousness of the students in the lecture, and the solution students must obey the rules of the learning model.
\end{abstract}

Keywords: Improving Learning Outcomes, Snowball Throwing. 


\section{PENDAHULUAN}

Pembelajaran IPS di SMP sekarang menjadi kebutuhan yang mendesak. Hal ini sejalan dengan perkembangan zaman yang begitu cepat. Era global telah mengubah pola pikir manusia dengan datangnya informasi global. IPS merupakan salah satu pengetahuan yang sangat bermanfaat bagi kelangsungan hidup manusia, sehingga diperlukan pengembangan dan pemanfaatan IPS untuk kesejahteraan manusia. Oleh karena itu, siswa telah diperkenalkan sejak di bangku sekolah.

Upaya pelaksanaan pendidikan terus ditingkatkan yaitu dengan pemerataan pendidikan ke seluruh pelosok tanah air Indonesia, membangun sarana prasarana fisik maupun mental peningkatan mutu pendidikan dengan perbaikan kurikulum, peningkatan kualitas guru dan sebagainya. Tak kalah penting adalah menyadarkan masyarakat akan pentingnya pendidikan, karena tak jarang masih ada masyarakat yang kurang mengerti akan tujuan pendidikan.

Jika memperhatikan proses perkembangan kurikulum pendidikan di Indonesia, sering sekali mengalami perubahan dalam hal materi maupun perangkatnya.

Pencapaian tujuan materi yang berkualitas meliputi strategi belajar mengajar dan metode pengajaran, dimana metode pengajaran sangat menentukan akan keberhasilan siswa dalam rangka pencapaian prestasi belajar siswa secara optimal.

Metode mengajar adalah suatu cara yang dipergunakan oleh guru untuk menyampaikan pengajaran dalam bidang-bidang studi di sekolah, selain mengajar guru juga memberikan latihanlatihan yang sesuai dengan materi yang telah diajarkan. Metode pengajaran dapat bersifat subyektif artinya suatu metode yang sesuai bagi seorang guru, belum tentu sesuai bagi guru yang lain. Hal ini disebabkan karena pribadi guru turut menentukan pemilihan metode yang dipakai.

Menyadari bahwa masih banyak guruguru yang belum berhasil meningkatkan prestasi belajar terhadap siswa, maka pihak Departemen Pendidikan Nasional mengadakan upaya bagi perbaikan untuk guru-guru berbagai usaha. Usaha perbaikan guru dapat berupa penataran bidang studi dan perubahan pada kurikulum.

Perubahan kurikulum maupun isinya kadang-kadang sering terjadi kesulitan khusus. Dan akibatnya prestasi anak akan menurun. Dalam hal tersebut di atas maka guru bidang studi IPS mempunyai tanggung jawab terhadap perkembangan prestasi belajar siswa untuk menyiapkan mereka hingga memecahkan masalahnya dan mampu mengembangkan prestasinya sesuai dengan kemampuan yang ada padanya.

Keberhasilan mengajar guru tidak hanya ditentukan penguasaan pengetahuan guru tentang ilmu yang diajarkan tetapi ditentukan faktor-faktor antara lain: tujuan, metode dan cara menerapkan dalam proses belajar mengajar.

Karena masing-masing metode mengajar mempunyai kelemahan dan kelebihan maka untuk mencapai hasil yang memuaskan antara metode yang satu dengan metode yang lain perlu panduan mengajar yang tepat, sehingga diharapkan kelemahan metode mengajar yang satu akan tertutup oleh metode yang lain. Pendidikan harus dapat membantu siswa untuk mengembangkan bakat potensi, kreatifitas yang dimiliki siswa secara penuh menuju pembentukan manusia seutuhnya. Hal ini sesuai dengan pengertian pendidikan dalam arti luas sebagai berikut:

Pendidikan adalah suatu usaha yang dilakukan secara sadar dan terencana untuk mewujudkan suasana dan proses pembelajaran agar peserta didik secara aktif mampu mengembangkan potensi yang ada didalam dirinya untuk memiliki kekuatan spiritual keagamaan, kepribadian yang baik, pengendalian diri, berakhlak mulia, kecerdasan,dan keterampilan yang diperlukan oleh dirinya dan masyarakat. (UU SISDIKNAS No.20 tahun 2003)

Untuk mewujudkan tujuan pendidikan perlu adanya upaya-upaya dalam penyelenggaraan pendidikan, disamping itu perlu adanya kesadaran anak didik yaitu bagaimana menempatkan diri di lingkungan pendidikan yang dialaminya. Hal ini tidak terlepas dari guru bagaimana menyampaikan materi pelajaran yaitu dengan menggunakan metode yang tepat. Karena metode pengajaran seorang guru merupakan salah satu dari aspek yang menentukan keberhasilan prestasi belajar siswa, maka seorang guru harus mau dan mampu meningkatkan profesionalismenya.

Umumnya pembelajaran IPS di sekolah masih menggunakan sistem konvensional, disamakan dengan mata pelajaran lain pada umumnya, dimana guru menerangkan, siswa mendengarkan dan mencatat, sehingga keterlibatan siswa di sini adalah keterlibatan pasif. Apalagi pelajaran IPS salah satu mata pelajaran yang kurang diminati siswa ditambah dengan banyak istilah-istilah IPS yang asing. Mereka hanya menerima tanpa banyak arti bagi siswa dikelas.

Selama ini, berdasarkan pengamatan peneliti, pembelajaran IPS khususnya yang dilaksanakan di SMP tidak menekankan pada keterampilan proses. Metode yang dominan, masih menggunakan ceramah sebagai metode pembelajaran yang utama. 
Menurut Sulistiyani (2000,76), dalam pendekatan keterampilan proses, metode ceramah bukanlah satu-satunya metode yang digunakan. Metode ceramah berfungsi mengantarkan siswa mendapatkan konsep melalui observasi dan eksperimen disamping panduan Lembar Kerja Siswa.

Melihat kenyataan tersebut, pada dasarnya proses pembelajaran IPS di SMP harus mampu menumbuhkan minat siswa melalui media-media yang sudah ada atau dirancang sendiri. Rangsangan tersebut meliputi fungsi psikomotor, kognitif dan afektif siswa sehingga belajar IPS jadi menyenangkan dan terbebas dari rasa membosankan.

Siti Nur' azizah (2000:42) dalam hasil penelitiannya menyebutkan bahwa pembelajaran dengan menggunakan pendekatan keterampilan proses memberikan kontribusi yang lebih baik terhadap prestasi belajar IPS dibandingkan dengan pembelajaran IPS yang menggunakan metode ceramah. Hal tersebut baik dilihat dan memperhatikan atau tanpa memperhatikan IQ dan kemampuan penalaran IPS Selanjutnya dijelaskan pula bahwa dengan pendekatan tersebut, siswa merasa tertarik dan memperoleh tantangan untuk aktif dan terampil agar dapat menemukan konsep, prinsip dan IPS sendiri dalam pengarahan guru. Dengan demikian pembelajaran IPS di SMP menjadi mata pelajaran yang menarik minat siswa untuk lebih mempelajari dan mendalaminya.

Bertitik tolak dari hal di atas, maka peneliti tertarik untuk meneliti "Meningkatkan Prestasi Belajar Siswa Kelas VIII F SMP Negeri 33 Surabaya Pada Mata Pelajaran IPS Materi Pranata Sosial Dengan Model Pembelajaran Snowball Throwing"

Berdasarkan hal-hal yang telah diuraikan di atas, secara rinci masalah yang diajukan dalam penelitian ini adalah :

1) Apakah penerapan model pembelajaran Snowball Throwing dapat meningkatkan kemampuan siswa VIII F SMPN 33 Surabaya?

2) Bagaimana meningkatkan aktivitas siswa VIII F SMPN 33 Surabaya dengan menggunakan model pembelajaran Snowball Throwing?

3) Bagaimana hasil belajar mata pelajaran IPS siswa kelas VIII F SMPN 33 Surabaya dengan menggunakan model pembelajaran Snowball Throwing?

4) Apakah kendala yang dihadapi guru dalam penerapan model pembelajaran Snowball Throwing terhadap siswa VIII F SMPN 33 Surabaya dan bagaimana solusinya?

Sesuai dengan rumusan masalah diatas maka tujuan penelitian ini untuk mengupayakan meningkatkan kualitas pembelajaran yaitu :
1. Bagi siswa, model pembelajaran Snowball Throwing untuk mata pelajaran IPS ini dapat meningkatkan kemampuan siswa kelas VIII F di SMPN 33 Surabaya dalam memahami materi mata pelajaran IPS.

2. Penggunaan model pembelajaran Snowball Throwing untuk mata pelajaran IPS dapat meningkatkan aktivitas siswa kelas VIII F di SMPN 33 Surabaya dalam mengikuti proses KBM di kelas.

3. Hasil belajar siswa kelas VIII F di SMPN 33 Surabaya menjadi lebih meningkat dengan diterapkannya model pembelajaran Snowball Throwing.

4. Kendala yang dihadapi peneliti yaitu terdapat siswa yang kurang serius dalam mengikuti KBM, dan situasi kelas lebih tidak teratur karena ada beberapa siswa yang tidak mentaati perintah guru serta adanya beberapa siswa yang pasif.

Penelitian ini berguna bagi guru, sebagai masukan terutama dalam memilih bahan ajar yang tepat dan efektif sehingga dapat mengoptimalkan prestasi belajar siswa, dan bagi Pengembangan Ilmu Pendidikan, dapat digunakan sebagai acuan yang dapat dijadikan sebagai pedoman dalam kegiatan belajar mengajar, serta membuka kesempatan bagi penelitian lebih lanjut tentang Penelitian Tindakan Kelas.

Dalam penelitian ini penulis berusaha agar pelaksanaannya dapat berjalan dengan baik dan efisien, maka diperlukan pembatasan masalah. Pembatasan ini dimaksudkan agar pembahasan penelitian mencapai tujuan yang diharapkan. Dengan pembatasan ini bukan berarti mengurangi sifat ilmiah suatu pembahasan, melainkan hanya mempersempit dan menyederhanakan ruang lingkup permasalahan.

\section{METODE}

Menurut Suwarsih Madya (1994:2) yang mengutip dari pendapat Kemmis dan Taggart, dikemukakan bahwa: Penelitian tindakan adalah suatu bentuk penelitian reflektif dan kolektif yang dilakukan oleh peserta-pesertanya dalam situasi sosial untuk meningkatkan penalaran dan keadilan praktik pendidikan dan praktik sosial mereka, serta pemahaman mereka terhadap praktik-praktik itu terhadap situasi tempat dilakukan praktik-praktik tersebut.

Penelitian tindakan kelas ini bertujuan antara lain untuk meningkatkan praktik, pemahaman praktik oleh praktisinya dan situasi tempat pelaksanaan praktik. Dalam penelitian ini yang akan dilakukan adalah untuk mengetahui pendekatan keterampilan proses dengan metode Snowball Throwing yang sesuai untuk diterapkan dalam proses pembelajaran IPS sehingga 
diharapkan dapat meningkatkan aktvitas dan motivasi belajar IPS siswa.

Untuk model pada penelitian tindakan kelas digunakan desain tindakan eksperimental yang prosesnya berlangsung secara terus-menerus menyerupai siklus sampai sasaran yang diinginkan melalui tindakan eksperimen itu dapat dicapai dan diperoleh pendekatan yang tepat untuk diterapkan. Berikut ini adalah siklus atau alur dalam penelitian tindakan kelas sebagaimana yang dikemukakan oleh Kemmis dan Tagart.

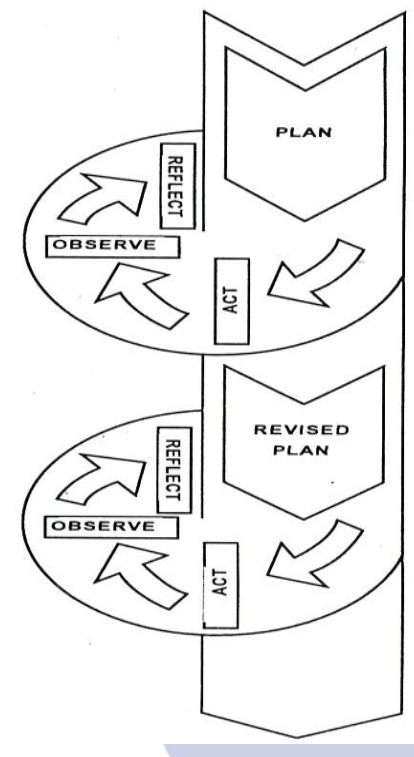

Model Pembelajaran Snowball Throwing Pengertian model pembelajaran Snowball Throwing Snowball Throwing adalah salah satu model pembelajaran kooperatif. Model pembelajaran ini dapat digunakan untuk memberikan konsep pemahaman materi yang sulit kepada siswa. Metode Snowball Throwing juga untuk mengetahui sejauh mana pengetahuan dan kemampuan siswa dalam menguasai materi tersebut.

Snowball secara etimologi berarti bola salju, sedangkan throwing artinya melempar. Snowball Throwing secara keseluruhan dapat diartikan melempar bola salju. Menurut Saminanto, metode pembelajaran Snowball Throwing disebut juga metode pembelajaran gelundungan bola salju. Metode pembelajaran ini melatih siswa untuk lebih tanggap menerima pesan dari siswa lain dalam bentuk bola salju yang terbuat dari kertas, dan menyampaikan pesan tersebut kepada temannya dalam satu kelompok. Sedangkan menurut (Kisworo, dalam Mukhtari, 2010: 6). metode pembelajaran Snowball Throwing adalah suatu metode pembelajaran yang diawali dengan pembentukan kelompok yang diwakili ketua kelompok untuk mendapat tugas dari guru kemudian masing-masing siswa membuat pertanyaan yang dibentuk seperti bola (kertas pertanyaan) lalu dilempar ke siswa lain yang masing-masing siswa menjawab pertanyaan dari bola yang diperoleh.

\section{Sedangkan}

langkah-langkah pelaksanaan pembelajaran Snowball Throwing Menurut Suprijono (2009 : 128) dan Saminanto (2010 : 37), langkah-langkah pembelajaran model pembelajaran Snowball Throwing adalah a) Guru menyampaikan materi yang akan disajikan dan KD yang ingin dicapai. b) Guru membentuk siswa berkelompok, lalu memanggil masing-masing ketua kelompok untuk memberikan penjelasan tentang materi. c) Masing-masing ketua kelompok kembali ke kelompoknya masing-masing, kemudian menjelaskan materi yang disampaikan oleh guru kepada temannya. d) Kemudian masingmasing siswa diberikan satu lembar kertas kerja, untuk menuliskan satu pertanyaan apa saja yang menyangkut materi yang sudah dijelaskan oleh ketua kelompok. f) Kemudian kertas yang berisi pertanyaan tersebut dibuat seperti bola dan dilempar dari satu siswa ke siswa yang lain selama \pm 5 menit. g) Setelah siswa dapat satu bola/satu pertanyaan diberikan kesempatan kepada siswa untuk menjawab pertanyaan yang tertulis dalam kertas berbentuk bola tersebut secara bergantian.

Kelebihan dan kelemahan model pembelajaran Snowball Throwing

a) Kelebihan model pembelajaran Snowball Throwing adalah 1) Suasana pembelajaran menjadi menyenangkan karena siswa seperti bermain dengan melempar bola kertas kepada siswa lain. 2) Siswa mendapat kesempatan untuk mengembangkan kemampuan berpikir karena diberikesempatan untuk membuat soal dan diberikan pada siswa lain. 3) Membuat siswa siap dengan berbagai kemungkinan karena siswa tidak tahu soal yang dibuat temannya seperti apa. 4) Siswa terlibat aktif dalam pembelajaran. 5) Pendidik tidak terlalu repot membuat media karena siswa terjun langsung dalam praktek. 6) Pembelajaran menjadi lebih efektif. 7)Ketiga aspek yaitu aspek kognitif, afektif dan psikomotor dapat tercapai.

b) Kelemahan model pembelajaran Snowball Throwing adalah 1) Sangat bergantung pada kemampuan siswa dalam memahami materi sehingga apa yang dikuasai siswa hanya sedikit. Hal ini dapat dilihat dari soal yang dibuat siswa biasanya hanya seputar materi yang sudah dijelaskan atau seperti contoh soal yang telah diberikan. 2) Ketua kelompok yang tidak mampu menjelaskan dengan baik tentu menjadi penghambat bagi anggota lain untuk memahami materi sehingga diperlukan waktu yang tidak sedikit untuk siswa mendiskusikan materi pelajaran. 3) Tidak ada kuis individu maupun penghargaan kelompok sehingga siswa saat berkelompok kurang termotivasi untuk bekerja sama. Tapi tidak menutup kemungkinan bagi guru untuk menambahkan pemberiaan kuis individu dan 
penghargaan kelompok sehingga memerlukan waktu yang panjang, murid yang nakal cenderung untuk berbuat onar dan kelas sering kali gaduh karena kelompok dibuat oleh murid.

\section{Kerangka Berpikir}

Pembelajaran IPS hendaknya dirancang semenarik mungkin agar dapat menumbuhkembangkan kemampuan siswa secara maksimal. Untuk itu dalam penelitian ini akan diterapkan model pembelajaran kooperatif tipe Snowball Throwing untuk meningkatkan prestasi belajar berdasarkan pada mata pelajaran IPS siswa kelas VIII F SMPN 33 Surabaya Kota Surabaya Tahun Pelajaran 2013/2014.

Pada model pembelajaran Snowball Throwing nantinya siswa diarahkan untuk belajar mandiri serta dilatih untuk mengoptimalkan kemampuanya dalam memahami informasi yang ilmiah yang dicari, dilatih untuk menjelaskan temuanya kepada pihak lain dan dilatih untuk memecahkan masalah. Dengan kata lain melalui metode ini siswa diajak berpikir dan memahami materi, tidak hanya mendengar, menerima dan mengingat saja. Tetapi juga dengan metode ini keaktifan, kemandirian, dan keterampilan siswa dapat dikembangkan, sehingga dengan diterapkanya kedua model pembelajaran ini diharapkan pemahaman siswa terhadap materi yang disampaikan dalam kegiatan pembelajaran akan lebih mudah dipahami oleh siswa, dan pada akhirnya akan berdampak pada prestasi belajar siswa yang baik.

\section{Hipotesis Tindakan}

Ho : Penggunaan Model Pembelajaran Snowball Throwing dalam Pembelajaran IPS materi Pranata Sosial di kelas VIII F SMPN 33 Surabaya Kota Surabaya tidak berpengaruh pada peningkatan kualitas belajar siswa.

$\mathrm{Ha}$ : Penggunaan Model Pembelajaran Snowball Throwing dalam Pembelajaran IPS materi Pranata Sosial di kelas VIII F SMPN 33 Surabaya Kota Surabaya tidak berpengaruh pada peningkatan kualitas belajar siswa.

Subyek dalam penelitian ini adalah siswa kelas VIII F SMP Negeri 33 Surabaya Kota Surabaya sebanyak 32 siswa dengan jumlah lakilaki 12 anak dan jumlah perempuan 20 anak.

Pemilihan ini berdasarkan nilai rata-rata ulangan semester 2 tahun pelajaran 2013/2014 siswa yang tuntas sebesar $61,11 \%$ lebih rendah dari kelas yang lainnya, dengan materi Pranata Sosial dimana pada tahun pelajaran sebelumnya masih banyak siswa yang nilainya belum mencapai KKM (kurang dari 75).

Penelitian ini menggunakan rancangan Penelitian Tindakan Kelas (Classroom based action research). Dalam penelitian ini guru juga sekaligus bertindak sebagai peneliti.
Model rancangan penelitian ini mengacu pada model yang dikemukanan oleh Kemmis dan Tagart (1998) dengan dua siklus. Masingmasing siklus terdiri dari empat tahap yaitu 1) Tahap penyusunan rencana tindakan. 2) Tahap pelaksanaan Tindakan. 3) Tahap observasi. 4) Tahap refleksi

\section{Tahap 1. Penyusunan Rencana Tindakan}

Pada tahap penyusunan rencana tindakan ini, guru mula-mula untuk tahap ini adalah memeriksa kembali nilai rata-rata ulangan harian, jurnal guru, Buku IPS untuk SMP, serta materi pelajaran berdasarkan kurikulum 2006. Sebagai implementasi tindakan dipilih konsep Pranata Sosial.

Setelah siswa mempelajari dan memahami konsep tersebut, maka akan disusun rencana pembelajaran. Sebagai latar pembelajaran akan digunakan Lembar Kegiatan Siswa yang dimodifikasi oleh guru. Pada akhir pelajaran, masing-masing siswa diberi tugas secara garis besar menjelaskan pentingnya klasifikasi tumbuhan.

\section{Tahap 2. Pelaksanaan Tindakan}

Pelaksanaan tindakan dimulai dengan menyebutkan membuat perbandingan ciri-ciri makhluk hidup. Sebagai alat belajar digunakan lembar kegiatan siswa yang terdapat pada buku paket IPS. Pembelajaran dilakukan di kelas seperti biasa. Tahap ini adalah merupakan tahap introduksi.

Tahap berikutnya siswa dibagikan lembar kerja siswa dan siswa mulai mengerjakan soal atau bahkan berdiskusi untuk menemukan jawaban dari pertanyaan-pertanyaan yang diberikan. Sambil mengamati kegiatan siswa, guru menunjuk salah satu siswa untuk menjawab pertanyaan.

\section{Tahap 3. Observasi}

Tahap ini dilakukan bersamaan dengan dibantu oleh teman guru IPS SMPN 33 Surabaya tahap pelaksanaan tindakan (action), selama proses pembelajaran berlangsung dilakukan observasi untuk memperoleh bahan bagi penyusunan refleksi.

Fokus observasi dilakukan terhadap pelaksanaan eksplorasi, situasi diskusi. Umpan balik dari siswa berupa lembar kertas kuisioner yang berisi pertanyaan tentang respon mereka terhadap kegiatan yang berlangsung.

Tahap 4. Refleksi

Kegiatan refleksi diawali dengan memeriksa catatan hasil observasi pemeriksaan dilakukan oleh guru. Kesan guru terhadap aktifitas siswa maupun respon siwa dicatat untuk dianalisa. Hasil pemeriksaan dikaji dan dievaluasi, kemudian dirumuskan sebagai refleksi dari pembelajaran siklus 1 . 


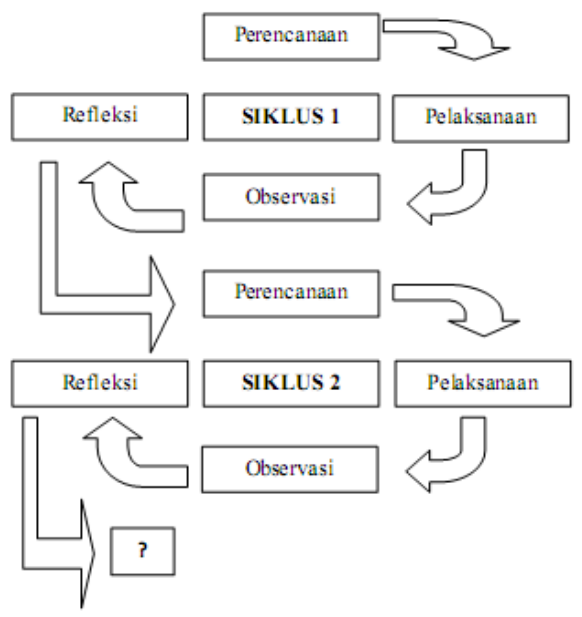

Gambar 3.1: Model TahapanTahapan Pelaksanaan PTK.

Sumber: Arikunto Suharsimi (2010:16) Teknik Pengumpulan Data

Untuk mengumpulkan

penelitian ini, diperlukan

data dalam pengumpulan data sebagai berikut:

teknik-teknik

1) Tes adalah serentetan pertanyaan atau latihan serta alat lain yang digunakan untuk mengukur ketrampilan, pengetahuan inteligensi, kemampuan atau bakat yang dimiliki oleh individu atau kelompok (Arikunto, 2006:150). Dalam penelitian ini tes digunakan untuk mengetahui peningkatan pemahaman siswa terhadapa materi tentang pranata sosial. Bentuk tes yang digunakan adalah tes uraian, karena tes bentuk uraian dapat menilai proses mental siswa terutama dalam hal kemampuan menyusun jawaban secara sistematis, kesanggupan menggunakan bahasa dan lain sebagainya. Tes ini dilaksanakan pada akhir siklus, setelah diberikan serangkaian tindakan.

2) Portofolio juga digunakan untuk mengetahui peningkatan pemahaman siswa tentang materi pranata sosial karena portofolio dapat melihat tahap perkembangan peserta didik dari waktu ke waktu. Proses ini akan membuat semua pihak, guru maupun peserta didik bisa mengenal kemajuan yang telah dicapai oleh peserta didik. Data-data yang dikumpulkan dalam portofolio ini berupa Lembar Kerja Siswa (LKS), tugas Pekerjaan Rumah (PR), dan jurnal belajar.

3) Wawancara yaitu suatu dialog yang dilakukan oleh pewawancara untuk memperoleh informasi dari terwawancara (Arikunto, 2006:155). Wawancara dalam penelitian ini dilakukan untuk memperdalam makna pemahaman terhadap materi pranata sosial serta menggali informasi tentang kelebihan dan kekurangan metode Snowball Throwing dengan penilaian portofolio yang diterapkan di kelas.
4) Observasi atau disebut juga dengan pengamatan adalah memperhatikan terhadap suatu obyek dengan menggunakan alat indra (Arikunto, 2006:156). Observasi dalam penelitian ini dilakukan untuk memperoleh data secara obyektif mengenai hal-hal yang terjadi selama pembelajaran berlangsung.

5) Catatan lapangan

Menurut Bogdan dan Biklen (dalam Moleong, 2006:209) catatan lapangan adalah catatan tertulis tentang apa yang didengar, dilihat, dialami, dan dipikirkan dalam rangka pengumpulan data refleksi terhadap data dalam penelitian kualitatif. Catatan lapangan ini mencakup catatan khusus siswa selama proses pembelajaran berlangsung yang tidak terdapat dalam lembar observasi.

\section{Instrumen Penelitian}

Penelitian ini dapat diperoleh data kuantitatif yaitu dengan mengukur tingkat keberhasilaan belajar siswa. Sedangkan data kualitatif adalah data yang tidak dapat diukur dengan angka-angka, tetapi dapat dilihat dampaknya setelah kegiatan pembelajaran berlangsung. Dalam penelitian ini fokus data kualitatif adalah dengan mengamati keterampilan guru, aktivitas siswa aspek afektif dan aspek psikomotor, selama mengikuti proses pembelajaran. Dalam hal ini peneliti endapat bantuan dari para kolaborator. Instrumen penelitian ini meliputi a) Lembar observasi aktivitas guru dan aktivitas siswa aspek afektif dan aspek psikomotor pada saat proses pembelajaran. b) Tes hasil belajar siswa sesudah tindakan berupa kuis evaluasi.

\section{Teknik Analisis Data}

Data hasil observasi pembelajaran dianalisis bersama-sama, kemudian ditafsirkan berdasarkan kajian pustaka dan pengalaman guru. Hasil belajar siswa dianalisis berdasarkan ketuntasan belajar siswa, yaitu $80 \%$ siswa sudah mencapai $75 \%$ taraf pengusaan konsep-konsep yang diberikan.

Uji hipotesa terhadap hipotesa yang dikemukakan pada awal penelitian ini akan diuji dengan menggunakan software SPSS. Data diuji dengan menggunakan statistik non parametrik.

\section{Deskripsi Hasil Penelitian}

Hasil penelitian ini dapat dikemukakan dalam 2 siklus, pada masing masing siklus dikemukakan hasil penelitian mengenai pelaksanaan pembelajaran IPS pada siswa kelas VIII F SMPN 33 Surabaya Kota Surabaya.

\section{Siklus 1}

\section{Perencanaan}

Kegiatan ini meliputi :

1) Menetapkan model pembelajaran yang digunakan, yaitu Snowball Throwing. 2)

Membuat Rencana Pelaksanaan Pembelajaran (RPP) dengan menggunakan model pembelajaran 
Snowball Throwing dengan materi tentang pranata sosial. 3) Membentuk kelompok yang terdiri dari 4-5 siswa secara acak. 4) Mempersiapkan media/alat pembelajaran berupa buku paket dan lembar kerja siswa. 5)Menyiapkan lembar observasi aktivitas guru dan aktivitas siswa berupa aspek afektif dan aspek psikomotor.6) Menyiapkan alat evaluasi berupa kuis.7) Menyiapkan lembar penilaian penghargaan tiap kelompok.

\section{Pelaksanaan Tindakan.}

Kegiatan yang dilaksanakan dalam tahap ini adalah melaksanakan kegiatan pembelajaran seperti yang telah direncanakan yaitu menggunakan model Snowball Throwing. Adapun tindakan yang dilakukan yaitu:

\section{1) Kegiatan Pendahuluan.}

a) Guru memeriksa kehadiran siswa, kebersihan dan kerapian kelas.b) Guru mengajukan pertanyaan yang mengaitkan pengetahuan sebelumnya dengan materi yang akan diajarkan. c) Guru menjelaskan tujuan pembelajaran yang akan dicapai siswa. d) Guru menginformasikan model pembelajaran yang akan digunakan.

\section{2) Kegiatan Inti.}

a) Eksplorasi. (1)Guru menjelaskan materi pembelajaran. (2) Guru mengelompokkan siswa menjadi 6 kelompok, yang beranggotakan 5-6 siswa. (3) Guru membantu setiap kelompok membagi tempat duduknya. b) Elaborasi. (1)Tiap siswa dalam tim diberi bagian materi yang berbeda (2) Masing-masing anggota kelompok menyusun pertanyaan yang ditulis di kertas dan dibentuk seperti bola(3) Bola kertas yang berisi pertanyaan tersebut siap dilempar kepada kelompok lain untuk dijawab(4) Setelah bola kertas berisi pertanyaan tersebut dijawab dikembalikan kepada siswa (kelompok) pelempar (5) Apabila siswa atau kelompok yang terkena lemparan tidak bisa menjawab pertanyaan pada bola tersebut, harus dilempar ke kelompok lain yang bukan kepada kelompok pelempar. (6) Kelompok/siswa penjawab (penerima pertanyaan) sudah selesai menjawab harus mendokumenkan pertanyaan-pertanyaan dari si pelempar. (7) Guru membimbing siswa saat kegiatan kelompok berlangsung, dan menanyakan kesulitan-kesulitan yang dihadapi siswa. (8) Guru mengevaluasi lembar kerja siswa yang telah dikerjakan dengan meminta salah satu kelompok menjawab secara bergantian kemudian kelompok lain menanggapi /melengkapi.(9) Guru membagikan lembar kuis atau evaluasi kepada setiap peserta didik untuk dikerjakan secara individu. c) Konfirmasi. Guru memberikan motivasi kepada siswa yang belum berpartisipasi aktif dalam kegiatan kelompok.

\section{3) Kegiatan Penutup}

a)Guru dengan siswa membuat kesimpulan terhadap materi yang telah diberikan.b)Guru menyampaikan rencana pembelajaran pada pertemuan berikutnya.

Dalam pembelajaran siklus 1, konsepkonsep yang diajarkan yaitu Pranata sosial. Dalam siklus 1, siswa dikelompokkan, masing-masing kelompok terdiri dari 5-6 orang untuk berdiskusi sesuai pertanyaan yang ada di lembar kerja siswa.

Model Pembelajaran Snowball Throwing ini memang cenderung ramai namun tetap dalam susana belajar yang menyenangkan.

c) Observasi

\section{Observasi Proses Pembelajaran}

Hasil observasi pada siklus I diperoleh gambaran tentang sikap dan perilaku siswa dalam hal kesungguhan siswa. Perhatian siswa mulai terpusat pada pelajaran walaupun belum maksimal. Sedangkan semangat siswa dalam mengikuti pelajaran IPS mulai meningkat. Siswa lebih bersemangat jika dibandingkan dengan kondisi awal sebelum model pembelajaran dengan teknik Snowball Throwing diterapkan.

Kemajuan siswa terlihat dalam hal keberanian mengemukakan pendapat. Berdasarkan tabel 4.1 dan tabel 4.2, pada umumnya siswa mulai berani mengemukakan pendapatnya, hal ini terlihat dari keaktifan siswa bertanya tentang materi yang belum dimengerti dan setiap siswa selalu berusaha menjawab pertanyaan dengan benar tanpa malu malu lagi. Keberanian siswa juga semakin terlihat ketika harus tampil untuk membaca dan menjawab pertanyaan. Nilai ketepatan dalam menjawab pertanyaan rata-rata $70,83 \%$ dalam kategori tinggi. Sementara itu ketepatan dalam membuat pertanyaan tiap kelompok rata-rata $82,5 \%$ dalam kategori sangat baik. Secara keseluruhan tingkat aktifitas siswa adalah $75,3 \%$ termasuk kategori baik.

Tabel 4.1. Hasil Penilaian Laporan Pada Siklus I

\begin{tabular}{|c|c|c|c|c|}
\hline \multirow{2}{*}{$\mathbf{N}$} & \multirow{2}{*}{$\begin{array}{c}\text { Kel } \\
\mathbf{0}\end{array}$} & & \multicolumn{3}{|c|}{$\begin{array}{c}\text { Komponen yang Diamati } \\
\text { Ketepatan } \\
\text { dalam } \\
\text { membuat } \\
\text { pertanyaan }\end{array}$} & $\begin{array}{c}\text { Ketepatan } \\
\text { dalam } \\
\text { menjawab } \\
\text { pertanyaan }\end{array}$ & $\begin{array}{c}\text { Nilai } \\
\text { Rata } \\
\text { - rata }\end{array}$ \\
\hline 1 & $\mathrm{~A}$ & 75 & 65 & $\mathbf{7 0}$ \\
\hline 2 & $\mathrm{~B}$ & 85 & 85 & $\mathbf{8 5}$ \\
\hline 3 & $\mathrm{C}$ & 90 & 85 & $\mathbf{8 7 , 5}$ \\
\hline 4 & $\mathrm{D}$ & 90 & 90 & $\mathbf{9 0}$ \\
\hline 5 & $\mathrm{E}$ & 75 & 45 & $\mathbf{6 0}$ \\
\hline 6 & $\mathrm{~F}$ & 80 & 55 & $\mathbf{6 7 , 5}$ \\
\hline $\begin{array}{c}\text { Rata }- \\
\text { rata }\end{array}$ & $\mathbf{8 2 . 5 0}$ & $\mathbf{7 0 , 8 3}$ & $\mathbf{7 6 , 7 6}$ \\
\hline
\end{tabular}


Meningkatkan Prestasi Belajar Siswa Kelas VIIIF SMP Negeri 33 Surabaya pada Mata Pelajaran IPS Materi Pranata Sosial dengan Model Pembelajaran Snowball Throwing

Mudjianingsih

Tabel 4.2. Tingkat Aktifitas Siswa Pada Siklus I

\begin{tabular}{|c|c|c|c|c|c|}
\hline \multirow[b]{2}{*}{$\begin{array}{l}\mathbf{N} \\
\mathbf{0}\end{array}$} & \multirow{2}{*}{$\begin{array}{l}\text { K } \\
\text { el }\end{array}$} & \multicolumn{4}{|c|}{ Komponem yang diamati } \\
\hline & & $\begin{array}{c}\text { Keteku } \\
\text { nan }\end{array}$ & $\begin{array}{c}\text { Kerjas } \\
\text { ama }\end{array}$ & $\begin{array}{l}\text { Antusi } \\
\text { asme }\end{array}$ & $\begin{array}{c}\text { Nilai } \\
\text { Rata- } \\
\text { rata }\end{array}$ \\
\hline 1 & A & 65 & 70 & 80 & 71,67 \\
\hline 2 & B & 80 & 70 & 80 & 76,67 \\
\hline 3 & $\mathrm{C}$ & 80 & 80 & 80 & 80 \\
\hline 4 & D & 95 & 80 & 80 & 85 \\
\hline 5 & $\mathrm{E}$ & 60 & 70 & 75 & 68,3 \\
\hline 6 & $\mathrm{~F}$ & 70 & 70 & 80 & 73,33 \\
\hline \multicolumn{2}{|c|}{$\begin{array}{c}\text { Rata- } \\
\text { rata }\end{array}$} & 75,00 & 73,33 & 79,17 & 75,83 \\
\hline
\end{tabular}

\section{Paparan Hasil Belajar}

Berdasarkan data hasil penelitian siklus I mengenai hasil belajar siswa pada materi Pranata Sosial melalui model pembelajaran partisipatif dengan teknik Snowball Throwing diperoleh data untuk nilai tertinggi yang diperoleh responden adalah 90 dan nilai terendah adalah 60 , serta rata-rata hasil belajar sebesar 73,13. Berdasarkan tabel 4.3, perolehan hasil belajar siswa melalui model pembelajaran dengan metode Snowball Throwing, $46 \%$ berada pada kategori baik sekali, 43,75\% baik, $15,63 \%$ cukup dan $31,25 \%$ kurang.

Adapun rata-rata hasil belajar siswa siklus I melalui model pembelajaran partisipatif dengan teknik Snowball Throwing adalah 73,13 dan ketuntasan individual baru mencapai $68,75 \%$. Hal ini memberikan indikator bahwa proses pembelajaran belum mencapai tujuan yang diharapkan guru yang tertuang dalam indikator kinerja lebih dari $85 \%$ dari jumlah siswa dalam kelas telah mencapai ketuntasan individual, sehingga perlu dilaksanakan siklus II.

Dalam siklus pertama ini, berdasarkan catatan peneliti, siswa masih kurang dapat bekerja sama, diskusi masih kurang dapat berjalan sebagaimana yang diharapkan. Pada saat presentasipun siswa masih belum betul-betul memahami tentang materi yang diajarkan.

Sesudah selesai presentasi, kepada siswa diberikan test, yang dapat ditunjukkan dalam tabel berikut ini:
Tabel 4.3

Nilai Siswa Kelas 8.F dalam Siklus 1

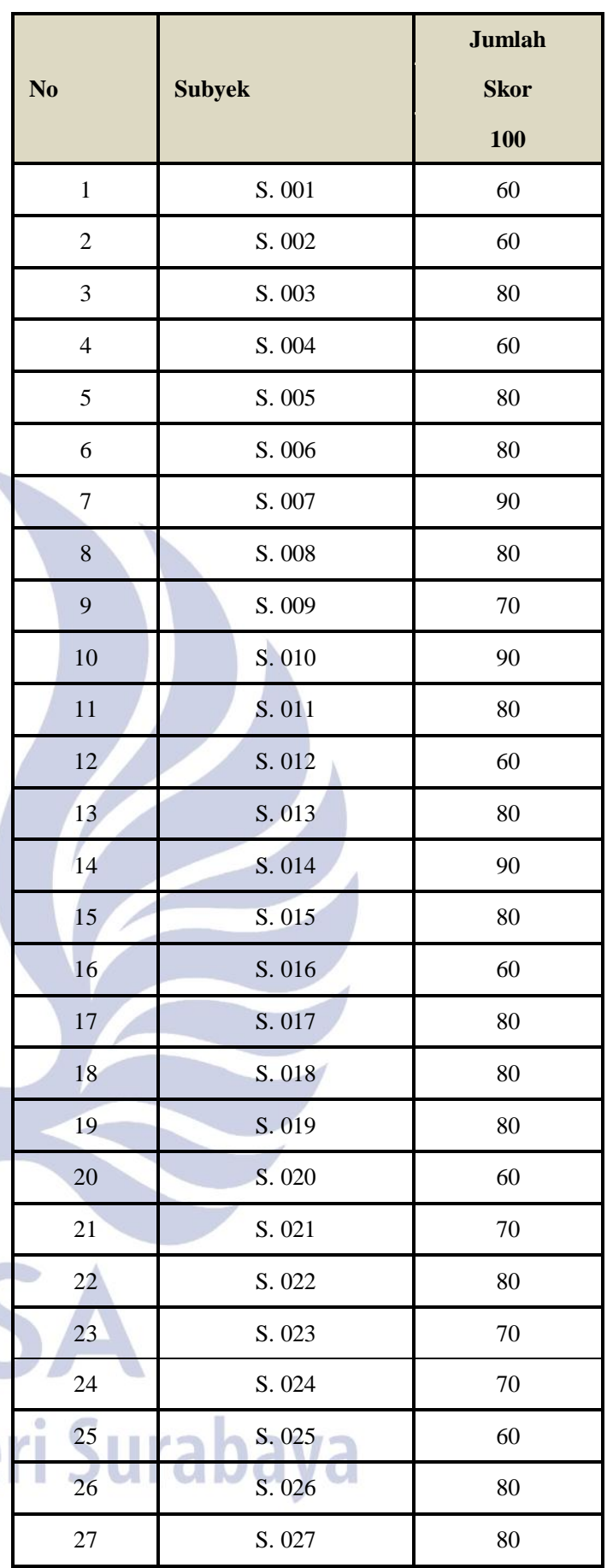




\begin{tabular}{|c|l|c|}
\hline 28 & \multicolumn{1}{|c|}{ S. 028 } & 60 \\
\hline 29 & \multicolumn{1}{|c|}{ S. 029 } & 80 \\
\hline 30 & \multicolumn{1}{|c|}{ S. 030} & 70 \\
\hline 31 & S. 032 & 60 \\
\hline 32 & \multicolumn{1}{|c|}{. } & 60 \\
\hline & Jumlah & $\mathbf{2 3 4 0}$ \\
\hline & Nilai rata-rata & $\mathbf{7 3 , 1 3}$ \\
\hline & Nilai tertinggi & $\mathbf{9 0}$ \\
\hline & Nilai terendah & $\mathbf{6 0}$ \\
\hline & Jumlah siswa yang tuntas & $\mathbf{2 2}$ \\
\hline & $\begin{array}{l}\text { Jumlah siswa yang tidak } \\
\text { tuntas }\end{array}$ & $\mathbf{1 0}$ \\
\hline & $\begin{array}{l}\text { Persentase siswa yang } \\
\text { tuntas }\end{array}$ & $\mathbf{6 8 , 7 5 \%}$ \\
\hline & $\begin{array}{l}\text { Persentase siswa yang } \\
\text { tidak tuntas }\end{array}$ & $\mathbf{3 1 , 2 5 \%}$ \\
\hline & Daya serap & $\mathbf{7 3 , 1 3 \%}$ \\
\hline
\end{tabular}

Dari tabel di atas tampak bahwa nilai ratarata siswa adalah 73,13 dengan nilai terendah 60 dan nilai tertinggi 90. Batas nilai ketuntasan adalah 65. Jumlah siswa yang mendapat nilai lebih atau sama dengan 65 adalah 22 siswa, yang berarti $68,75 \%$ dari sejumlah 32 siswa memiliki nilai diatas taraf penguasaan konsep yang diberikan.

Tabel. 4.4. Deskripsi Hasil Belajar Pada Siklus I

\begin{tabular}{|c|c|c|c|}
\hline $\begin{array}{c}\text { NILAI } \\
\text { INTERVAL }\end{array}$ & $\begin{array}{c}\text { f } \\
\text { (FREKUENSI) }\end{array}$ & PROSENTASE & $\begin{array}{c}\text { KRITERIA } \\
\text { NILAI }\end{array}$ \\
\hline $41-50$ & 0 & $0,00 \%$ & $\begin{array}{c}\text { Kurang } \\
\text { Sekali }\end{array}$ \\
\hline $51-60$ & 10 & $31,25 \%$ & Kurang \\
\hline $61-70$ & 5 & $15,63 \%$ & Cukup \\
\hline $71-80$ & 14 & $43,75 \%$ & Baik \\
\hline $81-90$ & 3 & $9,38 \%$ & Sangat Baik \\
\hline $91-100$ & 0 & $0,00 \%$ & Istimewa \\
\hline JUMLAH & 32 & $100,00 \%$ & \\
\hline
\end{tabular}

\section{d. Refleksi}

Berdasarkan hasil pengamatan dan analisis data pada siklus I, peneliti dapat merefleksikan kegiatan yang sudah dilakukan, maka didapat hasil sebagai berikut :

Karena guru pada saat membagi kelompok tidak berdasarkan penyebaran prestasi akademik, maka : (1) Presentasi tiap - tiap kelompok / individu kurang memuaskan (2) Persaingan antar kelompok belum terlihat, sehingga suasana kelas tidak dinamis. (3)Secara klasikal, hasil belajar siswa belum mencapai ketuntasan belajar

\section{Siklus 2}

\section{Perencanaan}

Kegiatan ini meliputi 1)Menetapkan model pembelajaran yang digunakan, yaitu Snowball Throwing. 2) Membuat Rencana Pelaksanaan Pembelajaran (RPP) dengan menggunakan model pembelajaran Snowball Throwing dengan materi pranata sosial 3) Membentuk kelompok yang terdiri dari 4-5 siswa secara acak. 4) Mempersiapkan media/alat pembelajaran berupa buku paket dan lembar kerja siswa. 5)Menyiapkan lembar observasi aktivitas guru dan aktivitas siswa berupa aspek afektif dan aspek psikomotor.6) Menyiapkan alat evaluasi berupa kuis.7) Menyiapkan lembar penilaian penghargaan tiap kelompok.

\section{Pelaksanaan Tindakan.}

Kegiatan yang dilaksanakan dalam tahap ini adalah melaksanakan kegiatan pembelajaran seperti yang telah direncanakan yaitu menggunakan model Snowball Throwing. Adapun tindakan yang dilakukan yaitu:

\section{1) Kegiatan Pendahuluan.}

a)Guru memeriksa kehadiran siswa, kebersihan dan kerapian kelas.b) Guru mengajukan pertanyaan yang mengaitkan pengetahuan sebelumnya dengan materi yang akan diajarkan. c) Guru menjelaskan tujuan pembelajaran yang akan dicapai siswa. d) Guru menginformasikan model pembelajaran yang akan digunakan.

\section{2) Kegiatan Inti.}

\section{A. Eksplorasi}

(1) Guru menjelaskan materi pembelajaran.

(2) Guru mengelompokkan siswa menjadi 6 kelompok, yang beranggotakan 5-6 siswa.

(3) Guru membantu setiap kelompok membagi tempat duduknya.

\section{B. Elaborasi}

(1) Tiap siswa dalam tim diberi bagian materi yang berbeda.(2) Masing-masing anggota kelompok menyusun pertanyaan yang ditulis di kertas dan dibentuk seperti bola.(3) Bola kertas yang berisi pertanyaan tersebut siap dilempar kepada kelompok lain untuk dijawab(4) Setelah bola kertas berisi pertanyaan tersebut dijawab dikembalikan kepada siswa (kelompok) pelempar. (5) Apabila siswa atau kelompok yang terkena lemparan tidak bisa menjawab pertanyaan pada bola tersebut, harus dilempar ke kelompok lain yang bukan kepada kelompok pelempar. (6) Kelompok/siswa penjawab (penerima pertanyaan) sudah selesai menjawab harus mendokumenkan pertanyaan-pertanyaan dari si pelempar.(7) Guru membimbing siswa saat kegiatan kelompok berlangsung, dan menanyakan kesulitan-kesulitan yang dihadapi siswa. (8) Guru mengevaluasi 
Meningkatkan Prestasi Belajar Siswa Kelas VIIIF SMP Negeri 33 Surabaya pada Mata Pelajaran IPS Materi Pranata Sosial dengan Model Pembelajaran Snowball Throwing

Mudjianingsih

lembar kerja siswa yang telah dikerjakan dengan meminta salah satu kelompok menjawab secara bergantian kemudian kelompok lain menanggapi /melengkapi.(9)Guru membagikan lembar kuis atau evaluasi kepada setiap peserta didik untuk dikerjakan secara individu.

\section{Konfirmasi.}

Guru memberikan motivasi kepada siswa yang belum berpartisipasi aktif dalam kegiatan kelompok.

\section{3) Kegiatan Penutup}

a) Guru dengan siswa membuat kesimpulan terhadap materi yang telah diberikan. b) Guru menyampaikan rencana pembelajaran pada pertemuan berikutnya.

Dalam pembelajaran siklus 1, konsepkonsep yang diajarkan yaitu pranata sosial. Dalam siklus II, siswa dikelompokkan, masing-masing kelompok terdiri dari 5-6 orang untuk berdiskusi sesuai pertanyaan yang ada di lembar kerja siswa. c. Observasi

Dalam pembelajaran siklus 2, konsepkonsep yang teridentifikasi, dikembangkan lebih lanjut yaitu siswa menjelaskan klasifikasi iklim, menganalisis persebaran curah hujan dab menyajikan informasi tentang persebaran curah hujan di Indonesia

Ada beberapa hal yang diminta untuk dicari jawaban dan didiskusikan dengan anggota kelompok, yaitu: menemukan jawaban dari pertanyaan (tersusun pada selembar kertas yang terbentuk seperti bola) yang terlempar ke arahnya kelompok lain. Pada tahap pembelajaran, siswa tetap diminta melakukan diskusi dan menjawab pertanyaan-pertanyaan tersebut di atas.

\section{Observasi Proses Pembelajaran}

Hasil observasi pada siklus II menunjukkan peningkatan yang cukup signifikan. Kesungguhan semangat siswa dalam mengikuti pelajaran IPS lebih meningkat. Seluruh siswa mengikuti pelajaran dengan penuh semangat, tidak ada yang malas atau kurang bersemangat dalam mengikuti pelajaran IPS.
Tabel 4.5. Hasil Penilaian Laporan Pada Siklus II

\begin{tabular}{|c|c|c|c|c|c|}
\hline \multirow{2}{*}{ No } & \multirow{2}{*}{ Kel } & \multicolumn{5}{|c|}{ Komponem yang diamati } \\
\cline { 3 - 6 } & & $\begin{array}{c}\text { Ketek } \\
\text { unan }\end{array}$ & $\begin{array}{c}\text { Kerj } \\
\text { asam } \\
\text { a }\end{array}$ & $\begin{array}{c}\text { Antusias } \\
\text { me }\end{array}$ & $\begin{array}{c}\text { Nilai } \\
\text { Rata- } \\
\text { rata }\end{array}$ \\
\hline 1 & $\mathrm{~A}$ & 85 & 80 & 80 & $\mathbf{8 1 , 6 7}$ \\
\hline 2 & $\mathrm{~B}$ & 90 & 80 & 85 & $\mathbf{8 5}$ \\
\hline 3 & $\mathrm{C}$ & 95 & 85 & 90 & $\mathbf{9 0}$ \\
\hline 4 & $\mathrm{D}$ & 90 & 80 & 85 & $\mathbf{8 5}$ \\
\hline 5 & $\mathrm{E}$ & 80 & 85 & 80 & $\mathbf{8 1 , 6 7}$ \\
\hline 6 & $\mathrm{~F}$ & 80 & 80 & 80 & $\mathbf{8 0}$ \\
\hline \multicolumn{7}{|l}{ Rata-rata } & $\mathbf{8 6 , 6 7}$ & $\mathbf{8 1 , 6 7}$ & $\mathbf{8 3 , 3 3}$ & $\mathbf{8 3 , 8 9}$ \\
\hline
\end{tabular}

Tabel 4.6. Tingkat Aktifitas Siswa Pada Siklus II

\begin{tabular}{|c|c|c|c|c|}
\hline \multirow[b]{2}{*}{$\begin{array}{l}\mathbf{N} \\
\mathbf{0}\end{array}$} & \multirow[b]{2}{*}{ Kel } & \multicolumn{3}{|c|}{ Komponen yang Diamati } \\
\hline & & $\begin{array}{c}\text { Ketepatan } \\
\text { dalam } \\
\text { membuat } \\
\text { pertanyaa } \\
\text { n } \\
\end{array}$ & $\begin{array}{c}\text { Ketepatan } \\
\text { dalam } \\
\text { menjawab } \\
\text { pertanyaan }\end{array}$ & $\begin{array}{c}\text { Nilai } \\
\text { Rata - } \\
\text { rata }\end{array}$ \\
\hline 1 & A & 100 & 75 & 87,5 \\
\hline 2 & B & 80 & 85 & 82,5 \\
\hline 3 & $\mathrm{C}$ & 90 & 90 & 90 \\
\hline 4 & $\mathrm{D}$ & 100 & 90 & 95 \\
\hline 5 & $\mathrm{E}$ & 80 & 75 & 77,5 \\
\hline 6 & $\mathrm{~F}$ & 100 & 80 & 90 \\
\hline & $\begin{array}{l}\text { ta }- \\
\text { ta }\end{array}$ & 91,67 & 82,50 & 87,08 \\
\hline
\end{tabular}

Keberanian siswa untuk mengemukakan pendapat juga semakin meningkat. Siswa sudah berani untuk mengungkapkan pendapat, mengomentari ataupun mengungkapkan ide-idenya. Hal lain juga semakin meningkat yaitu keberanian untuk membuat pertanyaan ataupun untuk menjawab pertanyaan. Para siswa berlomba-lomba untuk memperoleh pertanyaan dan menjawab pertanyaannya dengan tepat. Peningkatan ini juga terlihat pada kemampuan siswa untuk tampil di kelas dengan sebaik-baiknya. Berdasarkan Tabel 4.5, 82,5\% rata-rata siswa mampu menjawab pertanyaan dengan sangat baik, serta 91,67\% siswa memiliki kemampuan yang sangat baik untuk membuat pertanyaan yang bagus, mudah dipahami dan sesuai dengan materi, sehingga pelajaran dapat berlangsung dengan lancar, aktif, kreatif, bermakna dan menyenangkan. Secara keseluruhan tingkat aktifitas siswa 83,89\% termasuk kategori baik. Dengan suasana kelas yang demikian, ternyata siswa lebih mudah memahami materi pelajaran. Dari hal tersebut dapat ditarik kesimpulan bahwa 
Pembelajaran partisipatif dengan teknik Snowball Throwing dapat meningkatkan motivasi siswa kelas VIII F SMPN 33 Surabaya untuk belajar materi Pranata Sosial.

\section{Paparan Hasil Belajar Siswa}

Berdasarkan data hasil penelitian siklus II mengenai hasil belajar siswa pada materi Pranata Sosial melalui model Pembelajaran partisipatif dengan teknik Snowball Throwing diperoleh data untuk nilai tertinggi yang diperoleh responden adalah 90 dan nilai terendah adalah 80 , serta ratarata hasil belajar sebesar 93,75. Berdasarkan tabel 4.7, perolehan hasil belajar siswa melalui model Pembelajaran partisipatif dengan teknik Snowball Throwing, $37,50 \%$ berada pada kategori sangat baik, dan $62,50 \%$ berada pada kategori baik.

Dalam siklus pertama ini, berdasarkan catatan peneliti, kerjasama siswa sudah berjalan dengan baik, masing-masing tim ahli yang berkumpul untuk memecahkan masalah juga sudah dapat bekerja sama, anggota tim ahli yang harus mengajar kembali teman-temannyapun juga sudah dapat melakukan tugasnya dengan baik sebagaimana yang diharapkan. Pada saat presentasipun siswa sudah betul-betul memahami tentang materi yang diajarkan.

Sesudah selesai presentasi, kepada siswa diberikan test, yang dapat ditunjukkan dalam Tabe 1 4.7 berikut ini:

Tabel 4.7

Nilai Siswa dalam Siklus 2

\begin{tabular}{|c|c|c|}
\hline \multirow{2}{*}{ No } & Subyek & $\begin{array}{c}\text { Jumlah } \\
\text { Skor }\end{array}$ \\
\cline { 3 - 3 } & & $\mathbf{1 0 0}$ \\
\hline 1 & S. 001 & 80 \\
\hline 2 & S. 002 & 80 \\
\hline 3 & S. 003 & 90 \\
\hline 4 & S. 004 & 80 \\
\hline 5 & S. 005 & 80 \\
\hline 6 & S. 006 & 80 \\
\hline 7 & S. 007 & 90 \\
\hline 8 & S. 008 & 80 \\
\hline 9 & S. 009 & 90 \\
\hline 10 & S. 010 & 90 \\
\hline 11 & S. 011 & 80 \\
\hline 12 & S. 012 & 90 \\
\hline 13 & S. 013 & 80 \\
\hline 14 & S. 014 & 90 \\
\hline
\end{tabular}

\begin{tabular}{|c|c|c|}
\hline 15 & S. 015 & 80 \\
\hline 16 & S. 016 & 80 \\
\hline 17 & S. 017 & 90 \\
\hline 18 & S. 018 & 80 \\
\hline 19 & S. 019 & 80 \\
\hline 20 & S. 020 & 80 \\
\hline 21 & S. 021 & 90 \\
\hline 22 & S. 022 & 80 \\
\hline 23 & S. 023 & 90 \\
\hline 24 & S. 024 & 90 \\
\hline 25 & S. 025 & 80 \\
\hline 26 & S. 026 & 90 \\
\hline 27 & S. 027 & 80 \\
\hline 28 & S. 028 & 90 \\
\hline 29 & S. 029 & 80 \\
\hline 30 & S. 030 & 80 \\
\hline 31 & S. 031 & 80 \\
\hline 32 & S. 032 & 80 \\
\hline & Jumlah & 2680 \\
\hline & Nilai rata-rata & 83,75 \\
\hline & Nilai tertinggi & 90 \\
\hline & Nilai terendah & 80 \\
\hline & $\begin{array}{l}\text { Jumlah siswa yang } \\
\text { tuntas }\end{array}$ & 32 \\
\hline & $\begin{array}{l}\text { Jumlah siswa yang } \\
\text { tidak tuntas }\end{array}$ & $\mathbf{0}$ \\
\hline & $\begin{array}{l}\text { Persentase siswa } \\
\text { yang tuntas }\end{array}$ & $100,00 \%$ \\
\hline & $\begin{array}{l}\text { Persentase siswa } \\
\text { yang tidak tuntas }\end{array}$ & $\mathbf{0 , 0 0 \%}$ \\
\hline c & Daya serap & $83,75 \%$ \\
\hline
\end{tabular}

Dari tabel di atas tampak bahwa nilai ratarata siswa adalah 83,75 dengan nilai terendah 80 dan nilai tertinggi 90. Batas nilai ketuntasan adalah 75. Jumlah siswa yang mendapat nilai lebih besar atau sama dengan 75 ada 32 siswa, yang berarti $100.00 \%$ dari sejumlah 32 siswa memiliki nilai di atas taraf penguasaan konsep.

Adapun ketuntasan individual mencapai 93,75\%. Hal ini memberikan indikator bahwa proses pembelajaran sudah mencapai tujuan yang diharapkan guru yang tertuang dalam indikator kinerja lebih dari $85 \%$ dari jumlah siswa dalam kelas telah mencapai ketuntasan individual, sehingga penelitian tindakan kelas dinyatakan berhasil dan tidak perlu mengadakan siklus 
Meningkatkan Prestasi Belajar Siswa Kelas VIIIF SMP Negeri 33 Surabaya pada Mata Pelajaran IPS Materi Pranata Sosial dengan Model Pembelajaran Snowball Throwing

Mudjianingsih

berikutnya. Dengan demikian dapat ditarik kesimpulan bahwa penerapan pembelajaran partisipatif dengan teknik Snowball Throwing mampu meningkatan hasil belajar siswa kelas VIII F SMPN 33 Surabaya.

Tabel. 4.8. Deskripsi Hasil Belajar Pada Siklus II

\begin{tabular}{|c|c|c|c|}
\hline $\begin{array}{c}\text { Nilai } \\
\text { Interval }\end{array}$ & $\begin{array}{c}\text { F } \\
\text { (Frekuensi) }\end{array}$ & Prosentase & $\begin{array}{c}\text { Kriteria } \\
\text { Nilai }\end{array}$ \\
\hline $41-50$ & 0 & $0,00 \%$ & $\begin{array}{c}\text { Kurang } \\
\text { Sekali }\end{array}$ \\
\hline $51-60$ & 0 & $0,00 \%$ & Kurang \\
\hline $61-70$ & 0 & $0,00 \%$ & Cukup \\
\hline $71-80$ & 20 & $\mathbf{6 2 , 5 0 \%}$ & Baik \\
\hline $\mathbf{8 1 - 9 0}$ & $\mathbf{1 2}$ & $\mathbf{3 7 , 5 0 \%}$ & SB \\
\hline 91 - 100 & $\mathbf{0}$ & $\mathbf{0 , 0 0 \%}$ & Istimewa \\
\hline JUMLAH & 32 & $100,00 \%$ & \\
\hline
\end{tabular}

Dari siklus 2 ini dapat dikatakan bahwa proses pembelajaran telah berhasil mencapai apa yang sudah ditargetkan, sehingga secara keseluruhan dapat dikatakan bahwa proses pembelajaran sudah memenuhi apa yang diharapkan, yaitu adanya peningkatan kualitas pembelajaran yang ditunjukkan dengan peningkatan kualitas prestasi siswa secara menyeluruh.

Kesan siswa dalam penelitian ini dapat dijaring melalui kuisioner yang dibagikan. Untuk mendapatkan respon yang sesungguhnya, nama siswa tidak usah dituliskan.

Berdasarkan hasil penelitian pada siklus I dan II yang telah dilakukan, maka dapat ditarik kesimpulan bahwa pembelajaran partisipatif dengan teknik Snowball Throwing terbukti dapat meningkatkan aktivitas dan hasil belajar siswa kelas VIII F SMPN 33 Surabaya pada materi Pranata Sosial. Hal tersebut ditandai dari ketercapaian indikator keberhasilan penelitian tindakan kelas. keaktifan siswa dalam mengikuti pembelajaran terlihat semakin meningkat dari siklus I sebesar 68,75 \% dalam kategori baik menjadi $93,75 \%$ pada siklus II dalam kategori sangat baik. Demikian pula dalam hal hasil belajar siswa, terjadi peningkatan rata-rata hasil belajar dari siklus I sebesar 73,13 menjadi 83,75 pada siklus II.

\section{d. Refleksi}

Berdasarkan kepada hasil pengamatan dan analisis data pada siklus II, peneliti dapat merefleksikan kegiatan yang sudah dilakukan, maka didapat hasil sebagai berikut :

Karena guru pada saat membagi kelompok berdasarkan penyebaran prestasi akademik, maka : 1)Presentasi tiap - tiap kelompok / individu sangat memuaskan. 2)Persaingan antar kelompok sudah terlihat, sehingga suasana kelas dinamis. 3) Secara klasikal, hasil belajar siswa sudah mencapai ketuntasan belajar

\section{Pembahasan}

Tujuan pembelajaran IPS pada materi Pranata Sosial ini adalah siswa mampu untuk menganalisis tipe - tipe pranata sosial, menjelaskan klasifikasi pranata sosial dan menganalisis peran dan fungsi pranata sosial

Ditinjau dari hasil belajar yang ditunjukkan oleh nilai test pada siklus 1 dan siklus 2, maka dapat dikatakan bahwa proses pembelajaran ini sudah berhasil. Kekurangan yang terdapat pada Siklus 1, sudah diperbaiki pada siklus 2. Sehingga pada saat observasi dan refleksi pada siklus 2, sudah diperoleh gambaran yang menunjukkan peningkatan kualitas belajar siswa.

Hasil penelitian ini juga menunjukkan bahwa kualitas belajar siswa dapat ditingkatkan dengan diberikan perlakuan-perlakuan tertentu yang sesuai dengan materi materi yang harus dipelajari oleh siswa. Hal ini juga nampaknya dipengaruhi oleh gairah belajar yang dimiliki, karena model pembelajaran yang monoton saja akan membuat siswa bosan dan menganggap proses pembelajaran bukanlah suatu hal yang menarik.

Kegairahan belajar siswa juga ditunjukkan dengan partisispasi mereka yang meningkat selama diskusi berlangsung, ataupun juga kesiapan tim ahli pada saat mempresentasikan hasil diskusi kelompok mereka.

Siswa yang memiliki kekurangan juga dapat belajar pada temannya, ini adalah suatu hal yang menguntungkan, karena dengan belajar melalui temannya resistensi seperti rasa segan, malu untuk bertanya jika tidak mengerti akan dapat dikurangi jika dibandingkan mereka harus bertanya langsung kepada pada guru. Belajar bersama teman sebaya memang lebih efektif jika potensi intelektual siswa tinggi, namun demikian dengan dibiasakan siswa melakukan diskusi akan meningkatkan prestasi belajar siswa.

Indikator yang jelas terbaca dari penelitian tindakan kelas ini adalah meningkatnya nilai rata-rata kelas, tingkat pemahaman siswa, serta nilai tertinggi dan terendah yang berhasil dicapai oleh siswa selama dalam penelitian.

\section{Pengujian Terhadap Hipotesa}

Hipotesa yang dikemukakan pada bagian awal penelitian ini adalah sebagai berikut:

Ho : Pembelajaran IPS di kelas VIII.F SMPN 33 Surabaya Kota Surabaya tidak akan berpengaruh pada peningkatan kualitas belajar siswa.

$\mathrm{Ha}$ : Pembelajaran IPS di kelas VIII.F SMPN 33 Surabaya Kota Surabaya akan berpengaruh pada peningkatan kualitas belajar siswa.

Kasus di atas terdiri atas dua sampel yang berhubungan satu sama lain, karena setiap subjek 
(dalam hal ini para siswa) mendapat pengukuran yang sama yaitu diukur pada siklus 1 dan siklus 2 .

Data hanya sedikit dan dianggap tidak diketahui distribusi (berdistribusi bebas). Maka digunakan uji nonparametrik dengan dua yang sampel yang berhubungan (dependent).

Dalam analisa ini, digunakan SPSS, dengan pilihan menu adalah statistik non parametrik (Non Parametric Test), menggunakan Related samples, untuk uji dua sampel yang berhubungan. Model yang digunakan adalah Uji Peringkat-Bertanda Wilcogon Test. Hasil yang diperoleh adalah sebagai berikut:

\section{Wilcoxon Signed Ranks Test Ranks}

\begin{tabular}{|c|c|c|c|c|}
\hline \multicolumn{5}{|c|}{ Ranks } \\
\hline & & $\mathrm{N}$ & $\begin{array}{l}\text { Mean } \\
\text { Rank }\end{array}$ & $\begin{array}{l}\text { Sum of } \\
\text { Ranks }\end{array}$ \\
\hline \multirow[t]{4}{*}{$\begin{array}{l}\text { POSTEST } \\
\text { PRETEST }\end{array}$} & $\begin{array}{l}\text { Negative } \\
\text { Ranks }\end{array}$ & $0^{\mathrm{a}}$ & &, 00 \\
\hline & $\begin{array}{l}\text { Positive } \\
\text { Ranks }\end{array}$ & $18^{\mathrm{b}}$ & 9,50 & 171,00 \\
\hline & Ties & $14^{\mathrm{c}}$ & & \\
\hline & Total & 32 & & \\
\hline
\end{tabular}

a. POSTEST < PRETEST

b. POSTEST $>$ PRETEST

c. POSTEST $=$ PRETEST

Dari output SPSS di atas tampak bahwa nilai siswa yang turun pada siklus 2 adalah NIHIL, nilai siswa yang naik pada siklus 2 sebanyak 18 orang, sedangkan nilai siswa yang tetap adalah sebanyak 14 orang.

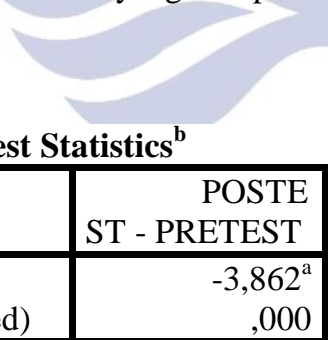

a. Based on negative ranks.

b. Wilcoxon Signed Ranks Test
Syarat untuk Keputusan uji hipotesa adalah : Probabilitas > 0,05 maka Ho diterima Probabilitas < 0,05 maka Ho ditolak.

Karena nilai Exact Sign. (2-tailed) adalah sebesar $0.035<0.05$, maka Ho ditolak. Dengan demikian Ha diterima, berarti bahwa Pembelajaran IPS materi Pranata Sosial untuk siswa kelas VIII F SMPN 33 Surabaya, Kota Surabaya mampu menarik dan meningkatkan prestasi belajar IPS.

\section{PENUTUP}

Kesimpulan yang dapat diperoleh dari hasil penelitian dan pemba-hasan ini adalah:

1. Bagi siswa, model pembelajaran Snowball Throwing untuk mata pelajaran IPS ini dapat meningkatkan kemampuan siswa kelas VIII $F$ di SMPN 33 Surabaya dalam memahami materi mata pelajaran IPS, karena nilai Exact Sign. (2tailed) adalah sebesar $0.000<0.05$, maka Ho ditolak. Dengan demikian Ha diterima, berarti bahwa Pembelajaran IPS untuk siswa kelas VIII F SMPN 33 Surabaya, Kota Surabaya mampu menarik dan meningkatkan prestasi belajar IPS.

2. Penggunaan model pembelajaran Snowball Throwing untuk mata pelajaran IPS dapat meningkatkan aktivitas siswa kelas VIII $F$ di SMPN 33 Surabaya dalam mengikuti proses KBM di kelas. Dan hasil nilai rata - rata yang diperoleh mengalami peningkatan yang semula 83,89 menjadi 87,08

3. Hasil belajar siswa kelas VIII F di SMPN 33 Surabaya menjadi lebih meningkat dengan diterapkannya model pembelajaran Snowball Throwing, yaitu dari nilai rata-rata kelas yang semula 73,14 menjadi 78,37.

4. Kendala yang dihadapi peneliti yaitu terdapat siswa yang kurang serius dalam mengikuti KBM, dan situasi kelas lebih tidak teratur karena ada beberapa siswa yang tidak mentaati perintah guru serta adanya beberapa siswa yang pasif.

Saran-saran yang dapat disampaikan dalam laporan penelitian ini adalah :

1. Penelitian lebih lanjut tentang metode ini dapat dilakukan untuk kelas-kelas lain dengan materi yang berbeda.

2. Diharapkan guru mengenalkan dan melatihkan keterampilan proses dan keterampilan kooperatif sebelum atau selama pembelajaran agar siswa mampu menemukan dan mengembangkan sendiri fakta dan konsep serta dapat menumbuhkan dan mengembangkan sikap dan nilai yang dituntut.

3. Guru perlu menambah wawasannya tentang teori belajar dan model-model pembelajaran yang inovatif. Oleh karena perangkat yang dikembangkan dalam penelitian ini efektif digunakan dalam mengajarkan IPS, maka disarankan agar juga dikembangkan bagi sekolah-sekolah lainnya.

4. Agar pembelajaran dengan pendekatan keterampilan proses berorientasi pembelajaran kooperatif dapat berjalan, sebaiknya guru membuat perencanaan mengajar materi pelajaran, dan menentukan semua konsep-konsep yang akan dikembangkan. 
Meningkatkan Prestasi Belajar Siswa Kelas VIIIF SMP Negeri 33 Surabaya pada Mata Pelajaran IPS Materi Pranata Sosial dengan Model Pembelajaran Snowball Throwing

Mudjianingsih

\section{DAFTAR PUSTAKA}

Wayan Memes. 2000. Model Pembelajaran IPS di SMP. Proyek Pengembangan Guru Sekolah Dasar Direktorat Jenderal Pendidikan Tinggi Departemen Pendidikan Nasional. Jakarta

Asrori, Mohib. 2010. Penggunaan Model Belajar Snowball Throwing dalam Meningkatkan Keaktifan Belajar Menyimpulkan Isi Cerita yang Didengar pada Anak. Tersedia di

http://gurutrenggalek.blogspot.com/2010 /09/penggunaan-model-belajarsnowball.html. Diunduh pada 7 Januari 2012.

Bobbi DePorter. 2002. Quantum Teaching. Boston: Allyn Bacon.

Suwarsih Madya. 1994. Seri Metodologi Penelitian, Panduan Penelitian Tindakan. Lembaga Penelitian IKIP, Yogyakarta:

Supriyadi. (2000). Proses Pembelajaran Fisika. Yogyakarta : Jurusan Fisika, Universitas Negeri Yogyakarta.

Suyanto \& Djihad Hisyam. 2000. Refleksi dan Reformasi, Pendidikan di IPS Memasuki Milenium III, Adi Cita.Yogyakarta:

Depdiknas. 2001. Buku 1 Manajemen Peningkatan Mutu Pendidikan Berbasis Sekolah.
Jakarta: Depdiknas.

Joni, Is. 2009. Model-model Pembelajaran

Mukhtari. 2010. Bab I Penerapan Metode Pembelajaran Snowball Throwing Dengan Penilaian Portofolio dalam Upaya Untuk Meningkatkan Pemahaman Materi Segitiga Siswa Kelas VII A Smp Islam 02 Pujon Tahun Pelajaran 2007/2008. Tersedia di http://mukhtaribenk.blogspot.com/201 0/10/bab-ii-penerapan-metodepembelajaran.html. Diunduh Sabtu, 7 Januari 2012.

Nurdina, Tya. 2011. Pembelajaran Kooperatif Tipe STAD dan Snowball Throwing serta Contoh Penerapannya. Tersedia di http://tyanurdina.wordpress.com/2011/09/ 16/pembelajaran-kooperatif-tipe-staddan-snowball-throwing-serta-contohpenerapannya/. Diunduh pada Minggu, 11 Juli 2012

Widodo, Rachmad. 2009. Model Pembelajaran Snowball Throwing. Tersedia dihttp://wyw1d.wordpress.com/2009/11/ 09/model-pembelajaran-18-snowballthrowing/. Diunduh pada Selasa, 27 Desember 2011.

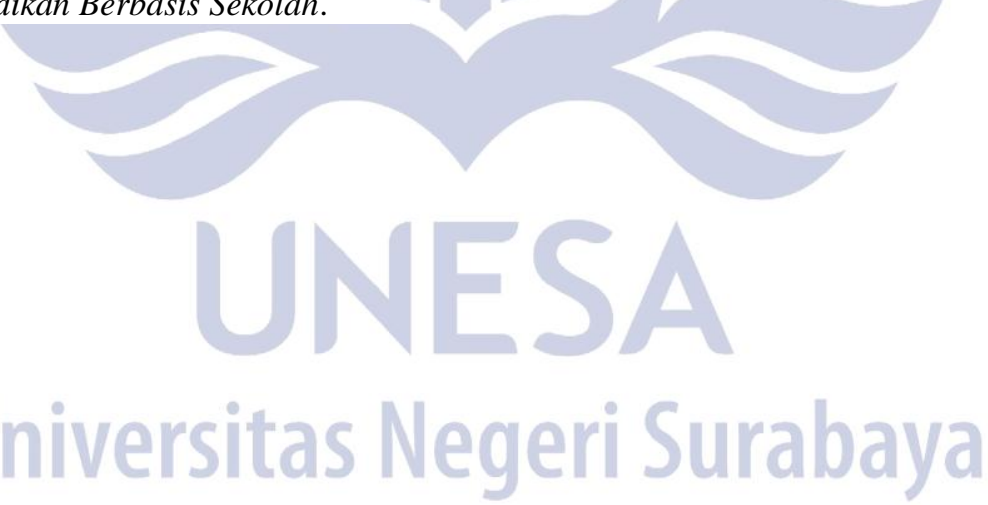

